Article

\title{
Fighting Corruption and Enhancing Tax Compliance through Digitization: Achieving Sustainable Development in Romania
}

\author{
Mina Fanea-Ivanovici ${ }^{1, * \mathbb{D}}$, Radu-Cristian Muşetescu ${ }^{2}$, Marius-Cristian Pană $^{1}$ and \\ Cristina Voicu ${ }^{1}$ \\ 1 Department of Economics and Economic Policy, Faculty of Theoretical and Applied Economics, \\ The Bucharest University of Economic Studies, 6 Romana Square, 010374 Bucharest, Romania; \\ marius.pana@economie.ase.ro (M.-C.P.); cristina.voicu@economie.ase.ro (C.V.) \\ 2 Department of International Business and Economics, Faculty of International Business and Economics, \\ The Bucharest University of Economic Studies, 41 Dacia Blvd., 010404 Bucharest, Romania; \\ radu.musetescu@rei.ase.ro \\ * Correspondence: mina.ivanovici@economie.ase.ro; Tel.: +40-762-639-155
}

Received: 4 February 2019; Accepted: 5 March 2019; Published: 11 March 2019

\begin{abstract}
Fighting corruption and enhancing tax compliance through digital public services represent key factors for increasing sustainable development in Romania. We argue that fighting corruption may increase the level of sustainable development, through digital pubic services. Using digital public services leads to the increase of the level of tax compliance, because entrepreneurs will feel more confident and responsible and they will decide to better comply. Tax regulations can affect the level of tax compliance through the additional costs they generate. The discussion is based on the consideration of the costs generated by compliant behavior and we explain how such costs influence the entrepreneurs' decision in the fiscal environment. If the costs are higher, entrepreneurs will take evasive initiatives and will refuse to comply. Among the numerous tools developed to fight corruption, the use of communication technologies has recently been researched and there is still need for further research in the Romanian economic environment. The use of digital public services reduces costs for entrepreneurs and increases their confidence in state institutions due to higher levels of transparency. We argue for increasing sustainable development in Romania through digital public services, thus fighting corruption and enhancing tax compliance.
\end{abstract}

Keywords: corruption; tax compliance; institutional arrangements; entrepreneurship; digital public services; digitization; sustainable development

\section{Introduction}

The aim of the present paper is to discuss the role of digitization, with a focus on digital public services and eGovernment, in increasing tax compliance and addressing corruption for improving sustainable development in Romania.

The discussion is based on the consideration of the costs generated by compliant behavior and we explain how such costs influence the entrepreneurs' decision in the fiscal environment. Do they decide to comply or do they choose to take evasive initiatives? How does corruption influence the level of sustainable development? How does digitization influence the level of tax compliance? How do entrepreneurs decide to comply by using digital public services?

Drawing on the existing literature, it becomes clear that in order to increase sustainable development it is necessary to reduce the level of corruption [1]. Such a conclusion requires both fighting corruption and enhancing tax compliance in Romania. Among the numerous tools developed 
to fight corruption, the use of communication technologies has recently been researched and there is still need for further research in the Romanian economic environment. Existing statistics indicate that no developing country is yet fully ready to embrace a comprehensive program of eGovernment. Therefore, we argue for increasing sustainable development in Romania through digital public services, thus fighting corruption and enhancing tax compliance.

The main findings of the article can be summarized as follows: the influence of entrepreneurial efforts made towards tax compliance is higher than the burden of the tax itself; burdensome tax regulations are a major determinant of the entrepreneurs' decision whether to pay taxes or not, but also a determinant of corruption in Romania; the possible implications of corruption, which can be both evasive and destructive, cannot be merely explained by tax regulations and the tax burden; Romania performs better in terms of environmental and economic sustainability and worse in terms of social sustainability; lower levels of corruption generate higher levels of responsibility, which in turn is positively correlated with sustainable development; Romania is still far from achieving digitization for paying taxes; the implementation of the existing system has led to a substantial decrease in the time spent to achieve tax compliance. The above correlations are discussed and validated in the paper from a narrow perspective regarding cost of tax compliance and entrepreneurial behavior. However, the occurrence and spread of corruption can be explained using a multitude of endogenous variables, which can be included in a more complex model that can demonstrate causality [2].

Corruption is a matter of great importance for any economy in the world and so is it for Romania. The risks revolving around corruption are associated with a broad spectrum of negative implications. Such implications progressively evolve from the political sphere undermining the rule of law to the economic sphere affecting sustainable development. From an economic perspective, sustainable development can be negatively affected by corruption. Corruption diminishes revenues that could otherwise be allocated through public budgets to contribute to the economic growth process, and alters the quality of the entrepreneurial activity. The possible implications belonging to the first category occur in the short run, and refer to the effects of tax evasion on budget revenues. They affect the quality of public services and diminish the resources needed to finance sustainable development. The second category includes long-run effects that influence the process of resource allocation through entrepreneurial activity. It has been widely argued in many studies that both short and long run effects have a negative impact on sustainable development [3]. Also, the need to analyze the costs of corruption on sustainable development is justified by the major impact of possible negative implications both in the short and in the long run. Researchers are trying to provide solutions for a better use of scarce resources in order to obtain a higher sustainable development score. The matter of organizing societies and human activity with the best efficiency possible was also researched by James M. Buchanan and Gordon Tullock in their work "The Calculus of Consent". All human actions involve opportunity costs. That is why we consider that organizing societies by trying to obtain a higher level of sustainable development is an important goal to be accomplished. In supporting this idea, we will refer to Machiavelli and his paper "The Discourses" — "in all human affairs one notices, if one examines them closely, that it is impossible to remove one inconvenience without another emerging .... . Hence in all discussions one should consider which alternative involves fewer inconveniences and should adopt this as the better course" [4] (p. 43).

We hereby analyze these possible correlations in the particular case of Romania, given that tax regulations affect the quality of entrepreneurship because they produce direct and indirect additional costs. The decision to be tax compliant is made based on the analysis of these costs and on their comparison with the costs of non-compliance. Influences on the quality of entrepreneurship occur as a result of changing entrepreneurial efforts and swiping entrepreneurs' behavior from productive initiatives towards evasive or destructive initiatives. The latter can be seen as a possible outcome but also a premise of the phenomenon of corruption, which could slow down the sustainable development process in Romania. This research highlights the role of public service digitization in reducing tax compliance costs and diminishing the phenomenon of corruption. 
Among the numerous tools developed to fight corruption, the use of communication technologies has recently been researched and there is still need for further research in the Romanian economic environment. There are still huge differences in using digital public services between developed countries and developing countries. No developing country is yet fully ready to embrace a comprehensive program of eGovernment, which is also the case of Romania.

The analysis of the implications of tax regulations on the quality of entrepreneurship can be analyzed in the broader context of the role of institutions in entrepreneurial activity. Economic literature, particularly in the field of institutional economics, provides significant contributions as to the importance of institutions as incentives or constraints on human behavior. In the most widely accepted form of the term, institutions are "the rules of the game in society". Their role is to ensure predictability of human actions and to structure the society in an orderly manner [5-7]. Informal institutions are the basis of the formal ones, which they influence, having consequences on the resource allocation process [8]. Institutions appear as factors of opportunities or constraints that influence the behavior of economic, social, and political actors, based on cost-benefit calculations. Thus, the analysis of institutions is made in terms of opportunity costs. When faced with certain rules, people choose alternative courses of action, to which opportunity costs are attached. Human behavior will conform to the rules insofar as repetitive actions have already-determined opportunity costs [9].

The specific influence of institutions on entrepreneurship benefits from a wide literature contribution, which can be grouped into the following categories [10]:

1. Productive, evasive, and destructive entrepreneurship. Institutions influence the quality of entrepreneurship, the latency or explosion of entrepreneurship being the result of incentives in the economy $[11,12]$. The quality of institutional arrangements leads entrepreneurial initiatives towards productive, unproductive, or destructive efforts [13-15]. The institution of private property law has an important position within these entrepreneurial delimitations as it is the decisive source for undertaking productive entrepreneurial initiatives [16]. Tax institutions transfer resources from productive entrepreneurs to interest groups that have or want to have political power. This produces a brutal reallocation of wealth and change in entrepreneurial behavior. All these justify the importance of institutional arrangements for economic growth [17-19].

2. Innovative entrepreneurship. It provides new products or services or it initiates and develops new methods to produce and distribute already existing goods at lower prices [20]. In addition, it takes responsibility, makes decisions based on judgments and changes the form and use of goods, resources, and institutions [21].

3. Institutional entrepreneurship. The interaction between entrepreneurship and institutions is not one-way. Institutions influence the quality of the entrepreneurial environment; in its turn, entrepreneurship shapes the institutional environment. The influence of entrepreneurship on institutional arrangements is based on three major sources: market innovation, evasive actions, and political innovation [22]. Thus, the institutional process is continually evolving. Public policy decision makers cannot claim to have identified the definitive and lasting institutional arrangement without taking into account the reaction of the entrepreneurial environment. Entrepreneurs' unexpected reactions require the re-evaluation of institutional choices. Institutional entrepreneurship is explained in terms of the actions of actors having interests in relation to certain institutional arrangements. These actors use resources to create new institutions or to improve the existing ones. In essence, the institutional entrepreneur is the individual who must take distance from the rules and practices associated with the dominant institutional arrangement and "institutionalize" new rules [23]. Productive entrepreneurship, viewed in terms of market initiatives whose role is to create wealth and improve living standards, is different from the one aimed to develop protective technologies. The latter refers to institutional entrepreneurship and seeks to provide the mechanisms that protect property rights, i.e., the essential institution required to involve entrepreneurs in productive activities [24]. 
4. Political entrepreneurship. It is similar to the one occurring under market conditions, although the major difference between the voluntary nature of market exchanges and the coercive nature of those stemming from the political processes is emphasized. Political profit arises when decision makers can ensure resource allocation at lower costs or, in the form of votes won from wealth allocation among different interest groups [25]. This leads to the emergence of incentives conducive to corruption, the decrease and/or diversion of public funds resulting from taxation and, consequently, the endangering of the process of sustainable development [26,27].

The extant literature includes research explaining the connection between the digitization process and its impact on fighting corruption. Such is the case of Bangladesh, where eGovernance strategies have been analyzed from the perspective of their contribution to fight corruption in an attempt to enhance development at community level. The implementation of a digital trust network to calculate and collect cumulative property tax was analyzed. Such tax is usually calculated and collected in an arbitrary way, but the new net-based local administration would render the process of tax assessment and collection transparent and, therefore, the willingness to pay taxes would increase [28]. EGovernment was also investigated by Irish researchers-their findings indicate that the use of electronic channels can represent a saving for tax authorities due to less direct communication with customers. Efforts have been made to increase taxpayers' awareness about such channels [29]. Although some authors argue that the introduction of eTaxation systems do not ensure the reduction of costs of tax compliance, they are unanimous in arguing that it does generate other non-financial positive outcomes such as accuracy and better compliance [30]. In this context, the main purposes of eGovernment strategies are to improve compliance, reduce contact with customers, and facilitate compliance [31].

Fighting corruption and enhancing tax compliance through digital public services represent key factors for increasing sustainable development [32]. Romania continues to be monitored by the European Commission for its performance in fighting corruption. Although the data of 2017 show that Romania had made great efforts to fight corruption there is still need for special attention in this area.

Fighting corruption may be considered a priority for any country, because all countries are affected by corruption, and societies are developing new structures of corruption through their collective action. That is why "if no collective action is required, there will be no need for a political constitution" [4] (p. 43). The matter of corruption is very old, but it still requires new approaches because it has been demonstrated in the literature that it strongly affects sustainable development. It is has been shown that the level of corruption in one country is negatively correlated with the level of democracy. Therefore, a high level of corruption is found in those countries where state institutions are undermined [33]. New forms of corruption have been developed inside societies and new measures must be adopted to fight against it.

\section{Materials and Methods}

The article is aimed at demonstrating the influence of digital public services on tax compliance and on corruption in general for the specific case of Romania. The present research is largely qualitative. However, descriptive statistics are also used, but to a lesser extent due to the fact that the digitization process is still in its early stages in Romania and there are no sufficient data to analyze larger time periods. In fact, continuous data on Digital Public Services, including eGoverment, in the European Union (EU) have been reported only since 2014 within the Digital Economy and Society Index (DESI). In Romania, the first real steps in digitizing public services were made in the year 2012. This is the main reason why data collection on and reporting of digital public services do not cover a longer period of time, which could enable a quantitative analysis.

In essence, the present research is built on the following four hypotheses, stipulating how digitization may improve tax compliance and reduce corruption, both of which leading to increased sustainable development in Romania: 
Hypothesis 1 (H1): Business taxation increases entrepreneurs' costs of tax compliance with Romanian tax regulations.

Hypothesis 2 (H2): Increasing costs of tax compliance can be correlated with corruption occurrence or spread in Romania.

Hypothesis 3 (H3): The spread of corruption endangers the process of sustainable development in Romania.

Hypothesis 4 (H4): Digitization improves tax compliance and reduces corruption, both of which leading to increased sustainable development in Romania.

According to Hypothesis 1, increased business tax regulations are positively correlated with the costs of tax compliance. This implies changes in the entrepreneurs' costs in the form of paid taxes and/or entrepreneurial efforts made for tax compliance, i.e., the time required to comply with specific procedures. It is expected that the time spent to comply with tax regulations is positively influenced by the number of taxes and procedures required to pay such taxes.

According to Hypothesis 2, the increasing effort for tax compliance stimulates the spread of the corruption phenomenon and of rent-seeking behaviors in the business environment, as well as of the state capture. Checking the validity of this hypothesis starts with accepting the relationship entrepreneurial behavior-institutional arrangements that prevails in the business environment. The quality of the business environment is determined by entrepreneurial behaviors occurring as a reaction to incentives and constraints.

According to Hypothesis 3, high levels of corruption negatively affect the level of sustainable development, by reducing responsibility among Romanian entrepreneurs. To test this hypothesis, we will identify proper elements to fight corruption and to enhance tax compliance in order to better use the country's present and future resources by its political decision makers, in order to increase sustainable development in Romania.

According to Hypothesis 4, digital pubic services may increase tax compliance and reduce corruption, in order to obtain higher levels of sustainable development in Romania. The use of digital public services decreases the costs for entrepreneurs and increases their confidence in state institutions thanks to a higher level of transparency. This creates prerequisites for higher revenues to the budget and for a better use of present and future resources. All arguments mentioned above are premises for a higher level of sustainable development in Romania.

The above-mentioned hypotheses can be graphically illustrated using the argument map presented in Figure 1.

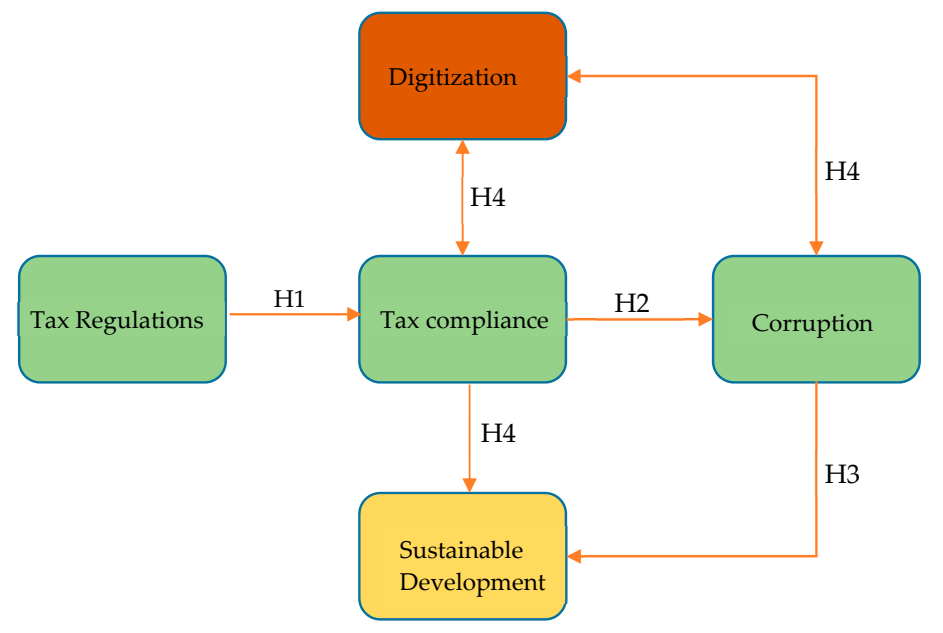

Figure 1. Argument map. 
Each of the four hypotheses is discussed in a separate subchapter in the next section of the paper. The data used in the analysis mostly refer to the time period 2006 to date. In fact, the first three hypotheses follow a logical step-by-step approach, while the fourth one appears as a conclusion drawn from all the previous ones. The logical sequence employed connects business taxation regulations, cost of tax compliance, corruption, and sustainable development. Based on evidence from the recent developments in the Romanian economy, the fourth hypothesis is also checked.

\section{Results}

\subsection{Hypothesis 1: Business Taxation Increases Entrepreneurs' Costs of tax Compliance with Romanian} tax Regulations

Tax regulations generate supplementary costs to entrepreneurs, in addition to the tax rates already applied on profit and property. For the purposes of this paper, we will refer to costs of tax compliance as the sum of entrepreneurs' efforts to compile all tax documents required by the governmental agency and the payment of taxes. Costs of tax compliance can be expressed in monetary terms-in the form of entrepreneurs' expenses generated by the employment of specialized personnel in the tax field and tax payment, and physically - the time spent for compiling and submitting tax documents with the governmental agency.

According to Hypothesis 1, increased business tax regulations are positively correlated with the costs of tax compliance. This implies changes in the entrepreneurs' costs in the form of paid taxes and/or entrepreneurial efforts made for tax compliance, i.e., the time required to comply with specific procedures. It is expected that the time spent to comply with tax regulations is positively influenced by the number of taxes and procedures requiring paying such taxes.

In order to check this hypothesis for the case of the Romanian business environment, we used data provided by the World Bank in the annual Doing Business Reports [34]. These reports include indicators that analyze the influence of the business environment regulations on its quality. For the stated purpose related to the first hypothesis, we used data included in the indicator 'Paying Taxes'. From a methodological point of view, it is worth noting that the data included in this section refer to the tax constraints applicable to a company of medium size in its second year of functioning. For instance, the data of the year 2006 refer to the tax regime of the year 2004. More precisely, three of the most relevant components of this indicator were selected: the number of taxes that have to be paid (Payments (number per year)), the time spent on compiling the required documents for tax compliance (Time (hours per year)) and the weight of paid taxes in the profit (Total tax rate (percentage of profit)). According to the Doing Business report methodology, the total tax in contribution rate measures the amount of taxes and mandatory contributions borne by the business in the second year of operation expressed as a share of commercial profit. Using this indicator and its three components, the report analyzes the taxes and mandatory contributions that a medium-sized company has to pay, as well as the administrative burden resulting from tax compliance. The methodology reveals that the indicators are calculated using data referring to the largest business city, which is the capital city, Bucharest. For the purposes of the present research, such data are representative, due to the fact that Bucharest concentrates a large share of the economic activity of the country. In addition, the choice of the data is justified by the fact that it is the only one available for Romania in this matter, for a longer time span and published with an annual frequency [35]. Moreover, we used data provided by World Economic Forum within the Global Competitiveness Index regarding the effects of taxation on the incentives to invest (Effect of taxation on incentives to invest) in Romania [36]. These data are presented in Table 1. 
Table 1. Paying taxes in Romania, 2006-2019.

\begin{tabular}{cccc}
\hline \multirow{2}{*}{ Year } & \multicolumn{3}{c}{ Paying Taxes } \\
\cline { 2 - 4 } & Payments (Number Per Year) & Time (Hours Per Year) & Total Tax Rate (Percentage of Profit) \\
\hline 2006 & 108 & 192 & 55.8 \\
2007 & 108 & 195 & 48.2 \\
2008 & 108 & 204 & 45.6 \\
2009 & 113 & 204 & 45.4 \\
2010 & 113 & 204 & 45.5 \\
2011 & 113 & 230 & 44 \\
2012 & 113 & 224 & 43.5 \\
2013 & 41 & 218 & 43.3 \\
2014 & 39 & 202 & 43.2 \\
2015 & 14 & 161 & 43.2 \\
2016 & 14 & 161 & 42 \\
2017 & 14 & 161 & 40 \\
2018 & 14 & 163 & 40 \\
2019 & 14 & 163 & 40 \\
\hline
\end{tabular}

The data included in the table above reveal the following conclusions: (1) there is a positive correlation between the change in the number of taxes due to be paid by the company and the number of hours required to fulfil compliance procedures, and this is true for the entire analyzed period of time. This relation is confirmed by the Pearson correlation coefficient (0.77); (2) the number of hours required to comply varies even if the number of payments remains constant. In fact, an increase in the number of hours is noticed. This finding indicates that the factor determining the cost of tax compliance is the number of procedures associated to compiling the documents required to pay taxes rather than the number of taxes that have to be paid annually. This can be correlated with the level of bureaucracy within the relation between the business environment and the tax governmental agency. As it can be noticed, in the periods 2006-2008, 2009-2012, and 2017-2019, the time spent to achieve tax compliance increased or recorded increasing fluctuations, although the number of taxes remained constant. A specific situation is that of tax compliance time for the period 2010-2012. It increased in 2011 despite the fact that the number of taxes remained the same. A possible explanation could be the introduction of a minimum tax profit, which increased the effort to be tax compliant. In 2012, the time spent to achieve tax compliance decreased as compared to the previous year, which can be explained by the repeal of the provisions regarding the minimum tax profit and by the introduction of an electronic tax payment system [37]. This last remark could also confirm the fourth hypothesis of the research, which concerns the beneficial role of digital public services for achieving tax compliance.

The influence of the number of procedures required for tax compliance on associated time and costs is obvious for the years 2013,2014, and 2015. As it can be noticed, the substantial reduction of the number of payments in the year 2013 as compared to the year 2012 (i.e., $63.8 \%$ ) led to a decrease by only 6 hours of the annual effort for tax compliance, which represents a decrease by only $2.7 \%$. However, eliminating two taxes in 2014 as compared to the year 2013 (a decrease of about $4.9 \%$ ) determined the reduction of the time needed for tax compliance by 16 hours annually (by approximately $7.4 \%$ ). The substantial reduction of the administrative tax burden took place starting with the year 2015, when the decrease by about $64 \%$ of the number of payments determined a reduction of the time to comply by almost $20 \%$.

The cost of compliance is measured by the weight of paid taxes in the company's profit. It is positively influenced by the change in the number of payments, which is also confirmed by the value of the Pearson correlation coefficient (0.66). Nevertheless, this connection is expectedly weaker than the correlation between the number of paid taxes and the time to comply. The explanation stands in the variation of individual weights of different taxes. This statement is justified by the data regarding 
the period 2009-2012, when for the same number of payments there was a decreasing weight of taxes in the company's profit (approximately 2 percentage points). Similarly, the same remark is validated by the data from the period 2015-2017 (a reduction by 3.2 percentage points of the weight of taxes in the profit for the same number of paid taxes).

A particular remark that can be made based on the data included in Table 1 stems from the comparative analysis of the number of paid taxes and the weight of taxes in profit for the period 2012-2015. The substantial reduction in the number of paid taxes left the cost of tax compliance almost unchanged (the weight of taxes in the profit). Thus, the latter diminished by only 0.3 percentage points although the number of paid taxes dropped from 113 (2012) to only 14 (2015). This suggests that the large majority of taxes existing in the year 2012 had negligible tax weights, but they would increase companies' efforts to comply in relation with the tax governmental agency.

The previous conclusions suggest that the main problem of tax compliance is not the cost of compliance per se (the weight of taxes in the total profit), but rather the time to comply and the number of taxes that have to be managed and paid by companies. The latter generate additional administrative costs, such as expenses with personnel specialized in the field of compiling tax documents. Decreasing these costs can be correlated with evasive entrepreneurial behaviors, which can actually lead to the spread of corruption. Such undesired correlation may occur especially when the effects of taxation on the business environment reduce the incentives to invest. Thus, leading entrepreneurial efforts towards activities meant to diminish the administrative burden and the costs related to tax compliance. The analysis of the data provided by World Economic Forum on the effects of taxation on incentives to invest for the case of Romania tends to confirm the fact that the values of this indicator are inversely correlated with the changes in the time needed to achieve tax compliance [36]. Thus, comparing the year 2015 to the previous one, the reduction of the time needed to comply is associated with an increase in the value of the indicator regarding the effects of taxation on incentives to invest (2.91 versus 2.63). This finding could suggest the increase in the entrepreneurs' optimism about the investment process. The values of the aforementioned indicator remained at a high level for the 2015-2018 as well, as a result of a reduction in the time needed to achieve tax compliance and of the weight of taxes in the profit.

\subsection{Hypothesis 2: Increasing Costs of tax Compliance Can be Correlated with Corruption Occurrence or Spread in Romania}

The increasing effort for tax compliance stimulates the spread of the corruption phenomenon and of rent-seeking behaviors in the business environment, as well as the state capture. Checking the validity of this hypothesis starts with accepting the relationship entrepreneurial behavior-institutional arrangements, which prevails in the business environment. The quality of the business environment is determined by entrepreneurial behaviors occurring as a reaction to incentives and constraints. Thus, such behaviors can be described starting from the comparative dimension of their associated benefits and compliance/non-compliance costs [38]. It is only to be expected that the comparative analysis of costs and benefits associated to tax payment compliance/non-compliance influences entrepreneurial behaviors in a predictable manner, as presented in Table 2. Entrepreneurial behaviors can be correlated with transaction costs, which, in their turn, determine the firm size. The costs of tax compliance appear as specific transaction costs, as they are costs arising from the interaction with the governmental agency [39-41]. 
Table 2. Types of entrepreneurial behaviors.

\begin{tabular}{ccc}
\hline $\begin{array}{c}\text { Entrepreneurial } \\
\text { Behaviors }\end{array}$ & $\begin{array}{c}\text { Transaction Costs Level (Compliance } \\
\text { Costs and Non-Compliance Costs) }\end{array}$ & $\begin{array}{c}\text { Costs and Benefits of State } \\
\text { Capture (Official and Unofficial) }\end{array}$ \\
\hline Productive & $\begin{array}{c}\text { Low level } \\
\text { Compliance costs are lower than } \\
\text { non-compliance costs }\end{array}$ & Benefits are lower than costs \\
\hline Elusive & $\begin{array}{c}\text { High level } \\
\text { Compliance costs are higher than } \\
\text { non-compliance costs }\end{array}$ & Benefits are lower than costs \\
\hline Destructive & $\begin{array}{c}\text { Low level } \\
\text { Compliance costs are higher than } \\
\text { non-compliance costs }\end{array}$ & Benefits are higher than costs \\
\hline
\end{tabular}

Source: [38].

Corruption-oriented and rent-seeking entrepreneurial behaviors are correlated with increasing costs of compliance associated with increased benefits from state capture. This means favoritism in allocating public funds, diversion of public funds, benefiting from tax exemptions or privileges, which are all forms under which corruption creates extra-market benefits for entrepreneurs. It is expected that a high level of corruption in the business environment is associated with destructive entrepreneurial behaviors.

Not only are entrepreneurial behaviors the mere mirroring of dominant institutional arrangements; in their turn, they put pressure in order to change the institutional framework to diminish the costs arising from the interaction with the governmental agency. Their influence is different depending on the firm size [42].

Checking Hypothesis 2 requires the comparative analysis of data regarding the cost of tax compliance and data on extra payments, bribes and favoritism in decisions of government officials, as they appear in the Report Economic Freedom of the World: 2018 Annual Report prepared by the Fraser Institute [43].

The data included in the figure below disclose the scores of the two indicators measured from 1 (worst) to 10 (best), according to the methodology used in the report [44]. Thus, the high scores of the indicator cost of tax compliance reflect the reduction of costs to comply, as a result of a decrease in the time required to compile tax documents and pay tax obligations, as per legal regulations. Conversely, lower scores indicate the increase of costs of tax compliance. The decreasing scores for the indicator Extra payments/bribes/favoritism reflect the worsening of the performance measured by this indicator. According to Hypothesis 2, there should be a positive correlation between the two indicators, i.e., increasing scores for the indicator cost of tax compliance should be associated with high scores for the other indicator. In order to check the hypothesis, cost of tax compliance was considered the independent variable, while extra payments/bribes/favoritism was the dependent variable.

The data from Figure 2 only partially confirms the hypothesis, i.e., for short time intervals. One can notice the existence of a negative relationship between the two variables, which is confirmed by the Pearson correlation coefficient $(-0.64)$. Regarded over the entire time span, the scores reveal that costs of tax compliance diminished, but there has been an increase in the intensity of corruption in the business environment as highlighted by evasive behaviors (extra payments/bribes) or destructive behaviors meant to obtain favors from government officials (favoritism). The same data also indicate a decrease in the perceived corruption in the business environment in the period 2006-2008 and a simultaneous high score for tax compliance. Such an evolution could be the outcome of adopting the flat tax rate in 2005 and of reforms implemented to harmonize national legislation with the European legislation and of the admission to the EU. 


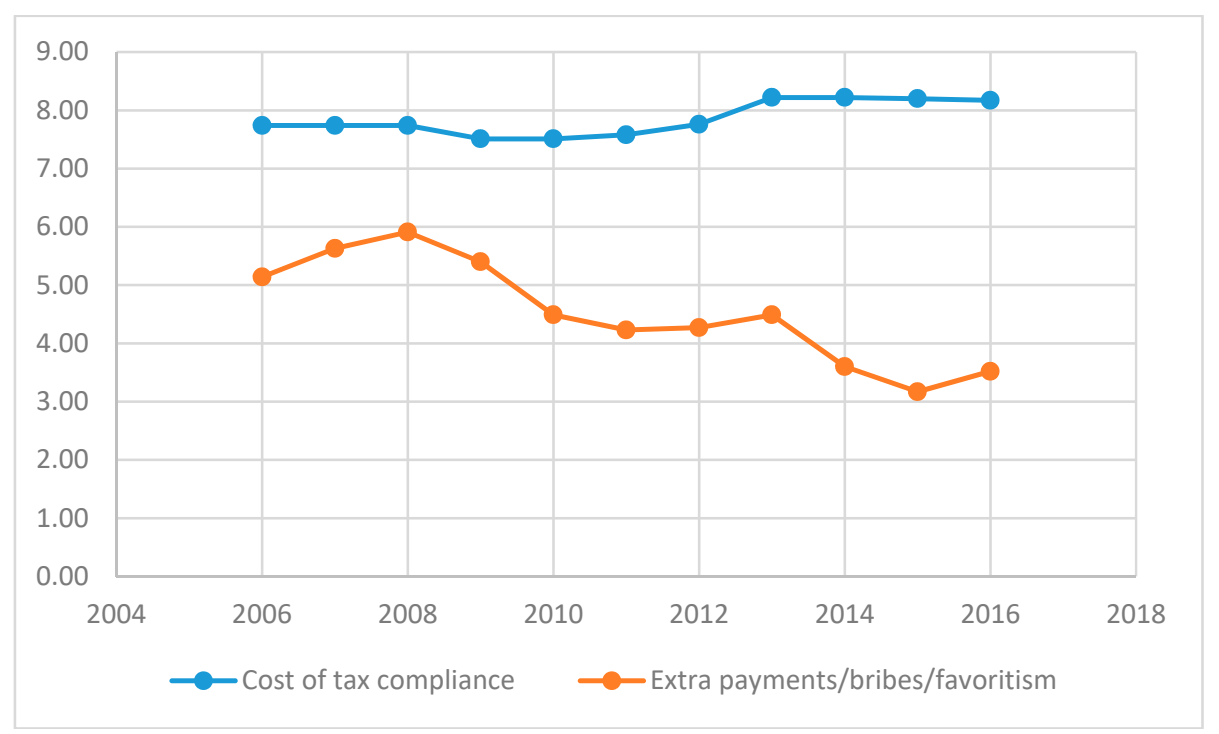

Figure 2. Cost of tax compliance and corruption in the business sector in Romania, 2006-2016. Source: [43].

Starting from 2009, the reduction in tax compliance costs is associated with the spread of evasive and destructive entrepreneurial behaviors. This indicates that the phenomenon of corruption in the business environment is wide and its explanation exceeds its mere association with the tax burden borne by entrepreneurs. It also indicates that the amount of the tax burden is not the main factor explaining corruption in the business environment. This statement is justified by the fact that tax compliance costs are not the only burden stemming from the regulation of the business environment by the governmental agency. Preparing the documents and paying the tax obligations are just a part of the whole process of starting and running a business in the existing legal framework at a certain time moment.

As concerns the relationship between the institutional framework and entrepreneurship, it is important to clarify the correlation between tax evasion and corruption. Although tax evasion is not necessarily placed only within the area of corruption, it can represent the starting point for more elaborate forms of corruption, including rent-seeking and state capture. Tax evasion is a type of evasive entrepreneurial behavior [5] (pp. 81-82).

In addition, the amplification of corruption in the Romanian business environment seems to be an issue of how the governmental agency carries out its responsibilities rather than an issue of government intervention in the business environment through increased tax regulation. Favoritism in decision of government officials and allocation of public funds as well as diversion of public funds create the possibility to initiate rent-seeking and state capture behaviors. Under these conditions, entrepreneurs display, to a lesser extent, a defensive behavior in correlation with a burdensome tax regulation framework. They tend to obtain benefits from the governmental agency under the form of public funds and/or tax exemption or tax benefits.

The previous statements can be confirmed by analyzing data on irregular payments and bribes, favoritism in decisions of government officials and diversion of public funds. The data were provided by World Economic Forum in the Global Competitiveness Report [36].

The data presented in Table 3 indicate the scores of the three indicators that constitute the Institution pillar used, alongside other 11 pillars used for calculating the Global Competitiveness Index by the World Economic Forum [45]. The quality of indicators is measured by scores from 1 (the worst) to 7 (the best). They reveal how common it is for firms to make undocumented extra payments or bribes to government officials to what extent government officials show favoritism to well-connected firms and individuals when deciding policies and contracts and how common illegal diversion of public funds is to companies, individuals, or groups [46]. 
Table 3. Corruption and government agency in Romania, 2006-2017.

\begin{tabular}{cccc}
\hline Year & $\begin{array}{c}\text { Irregular Payments and } \\
\text { Bribes }\end{array}$ & $\begin{array}{c}\text { Favoritism in Decisions of Government } \\
\text { Officials }\end{array}$ & $\begin{array}{c}\text { Diversion of Public } \\
\text { Funds }\end{array}$ \\
\hline 2006 & $*$ & 2.34 & 2.91 \\
2007 & $*$ & 2.34 & 3.17 \\
2008 & $*$ & 2.42 & 3.27 \\
2009 & $*$ & 2.34 & 3.25 \\
2010 & 4.36 & 2.39 & 3.08 \\
2011 & 3.97 & 2.47 & 2.79 \\
2012 & 3.73 & 2.38 & 2.55 \\
2013 & 3.79 & 2.24 & 2.51 \\
2014 & 3.89 & 2.55 & 3.01 \\
2015 & 3.63 & 2.43 & 2.92 \\
2016 & 3.59 & 2.21 & 2.81 \\
2017 & 3.98 & 2.25 & 3.12 \\
\hline
\end{tabular}

Source: [36]. Note: ${ }^{*}$-data not available.

The data provided in the table indicates that favoritism of government officials is perceived to be very high, which explains the very weak scores of this indicator. Similar scores are recorded as concerns the discretionary power of public authorities in allocating funds to certain private interest groups. They are associated with high levels of corruption perception. Low scores of the indicator regarding irregular payments and bribes could suggest the existence of a symbiotic relationship between the discretionary power of the governmental agency in decisions and allocating public funds and the level of corruption in the Romanian business environment.

As noticed from the data in Table 3, the costs of tax compliance are not perceived to be very high. They decrease for the analyzed time span. However, this means that irregular payments and bribes are used for: obtaining favors from government officials in decisions regarding the regulation of the business environment, awarding of public contracts and licenses and obtaining favorable judicial decisions. Similarly, high levels of favoritism in decisions and discretionary power in allocating public funds flag the need of a compromise translated into irregular payments and bribes. Originally, irregular payments and bribes could be seen as solutions to diminish entrepreneurs' costs. Such costs result from the interaction with the governmental agency (evasive entrepreneurship) under the conditions of proliferation of the governmental agency interventionism. Nevertheless, they ultimately tend to become ways of obtaining extra-market benefits to the detriment of competitors and taxpayers by creating interest groups (destructive entrepreneurship).

As per data in Table 3, the Romanian business environment seems to be described rather by the destructive entrepreneurship model, within which corruption and state capture are correlated. This model of entrepreneurship, whose coordinates are shaped by the dimension of discretionary power and favoritism of the governmental agency, is pernicious for the business environment and for the Romanian sustainable development. The possible implications of corruption, as stated in the conclusions above, can be grouped into two categories. On the one hand, they impair the quality of the business environment in the long run, turning it from a productive entrepreneurial environment into an evasive and potentially destructive one. This evolution destroys the main drive of sustainable development of an economy: entrepreneurship. On the other hand, it alters public budgets by diminishing and particularly diverting public resources through discretionary power and favoritism of the governmental agency. In the short run, they are prevented from functioning as solutions for developing the business environment and/or bridging gaps resulting from wealth redistribution in the society. 


\subsection{Hypothesis 3: The Spread of Corruption Endangers the Process of Sustainable Development in Romania}

Sustainable development in Romania is a country priority. In this hypothesis we argue that there is a negative correlation between the level of corruption and sustainable development. Considering the agenda for Sustainable Development adopted by All United Nation Member States in 2015, we primarily will focus on two goals regarding Romanian sustainable development: goal 16 and goal 17 [47]. By describing the way corruption is functioning, we identify proper elements to fight corruption and to enhance tax compliance in Romania in order to better use the country's present and future resources by its political decision makers and to increase sustainable development. This objective can be fulfilled by understanding how to reduce corruption and how to increase tax compliance through increasing citizens' confidence in state institutions by making available digital public services.

All around the world, and in Romania as well, political decision makers are struggling to find the best way to save resources for the best alternatives in society. Both developed and developing countries are fighting with poverty and inequality, while also trying to improve health, education, and economic growth.

Goal 16 promotes peaceful and inclusive societies for sustainable development, access to justice for all, and effective, accountable and inclusive institutions at all levels. In this paper we claim for solutions to enforce the role and involvement of institutions in promoting chances for all entrepreneurs to feel both confident and responsible when acting as economic agents. Every entrepreneur has to consider that in time these may be both reason and source of sustainable development.

A review of the Sustainable Development Agenda for 2030 referring to goal 16 states that "advances in promoting the rule of law and access to justice are uneven. However, progress is being made in regulations to promote public access to information, albeit slowly, and in strengthening institutions upholding human rights at the national level" [48]. Increasing citizens' confidence in state institutions could be positively correlated with the scores of the indexes of sustainable development. As it can be noticed in Figure 3 below, citizens' confidence is an index used by European Commission to express the perception regarding the confidence that citizens have in state institutions, such as government, national parliament, and political parties. Considering the data for 13 years (from 2004 to 2016) it is obvious that citizens' confidence decreased in the first 6 years, which is the period before Romania joined the EU; after the admission to the EU, citizens' confidence started to increase. For all three categories of institutions, the evolution follows the same trend. When comparing the intensities of the results, it is noticed that citizens' perception shows that political parties are considered to be less trustworthy, while the government is the most trustworthy of all three institutions.

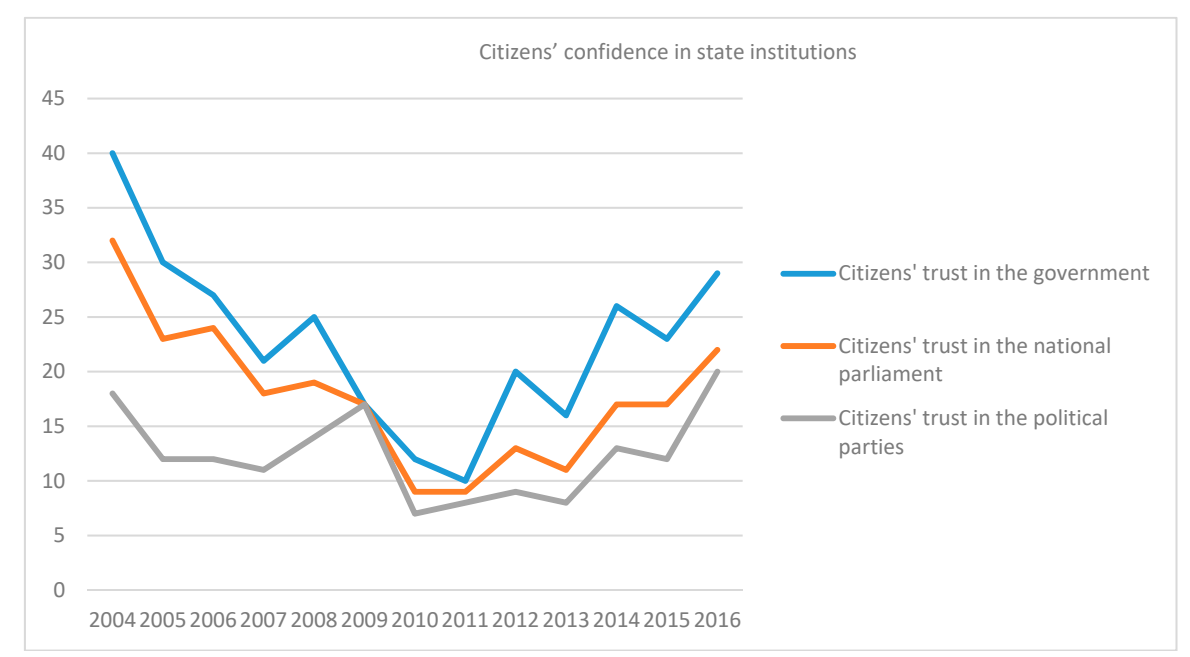

Figure 3. Romanian citizens' confidence in state institutions. Authors' design using data from the European Commission, Standard Eurobarometer 90. Source: [49]. 
When comparing Romanian citizens' perception regarding trust in state institutions with the average of the EU it results that in Romania, $68 \%$ of respondents say that they are personally affected by corruption and only $25 \%$ of Europeans have this perception. Most Europeans think that corruption is widespread among political parties $(56 \%)$ and politicians $(53 \%)$ and only a small minority thinks it is widespread among other categories. The large majority of Europeans think that corruption exists mostly in public institutions at local, regional and national levels. The lack of transparency and supervision of the financing of political parties leads to corruption. About $79 \%$ of Europeans agree that too-close relations between business and politics certainly leads to corruption [50].

A better supervision of this relation may be considered by decision makers in order to improve responsibility and diminish corruption.

Goal 17 aims to "strengthen the means of implementation and revitalize the global partnership for sustainable development" by bringing together national governments, the international community, civil society, the private sector and other actors" [51].

According to the Human Development Report in 2018, Romania ranked 52 out of 182 countries and the Human Development Index was 0.811 (the world index was 0.728) [52]. The data in the Human Development Report on Romania show that the sustainable development dashboard contains a selection of 15 key indicators covering environmental, economic and social sustainable development. Environmental sustainability indicators represent a mix of level and change indicators related to renewable energy consumption, carbon-dioxide emissions, change in forest area, and fresh water withdrawals. Forest area as percentage of the total land area is given in the table, but is not used for the comparison; instead, the total change in forest area between 1990 and 2015 is used. Economic sustainability indicators look at adjusted net savings, external debt stock, natural resource depletion, diversity of economy, and government's spending on research and development. Social sustainability is reflected by changes in income and gender inequality, multidimensional poverty, and the projected old age dependency ratio. Three-color coding is used to visualize partial grouping of countries by each indicator in Figure 4.

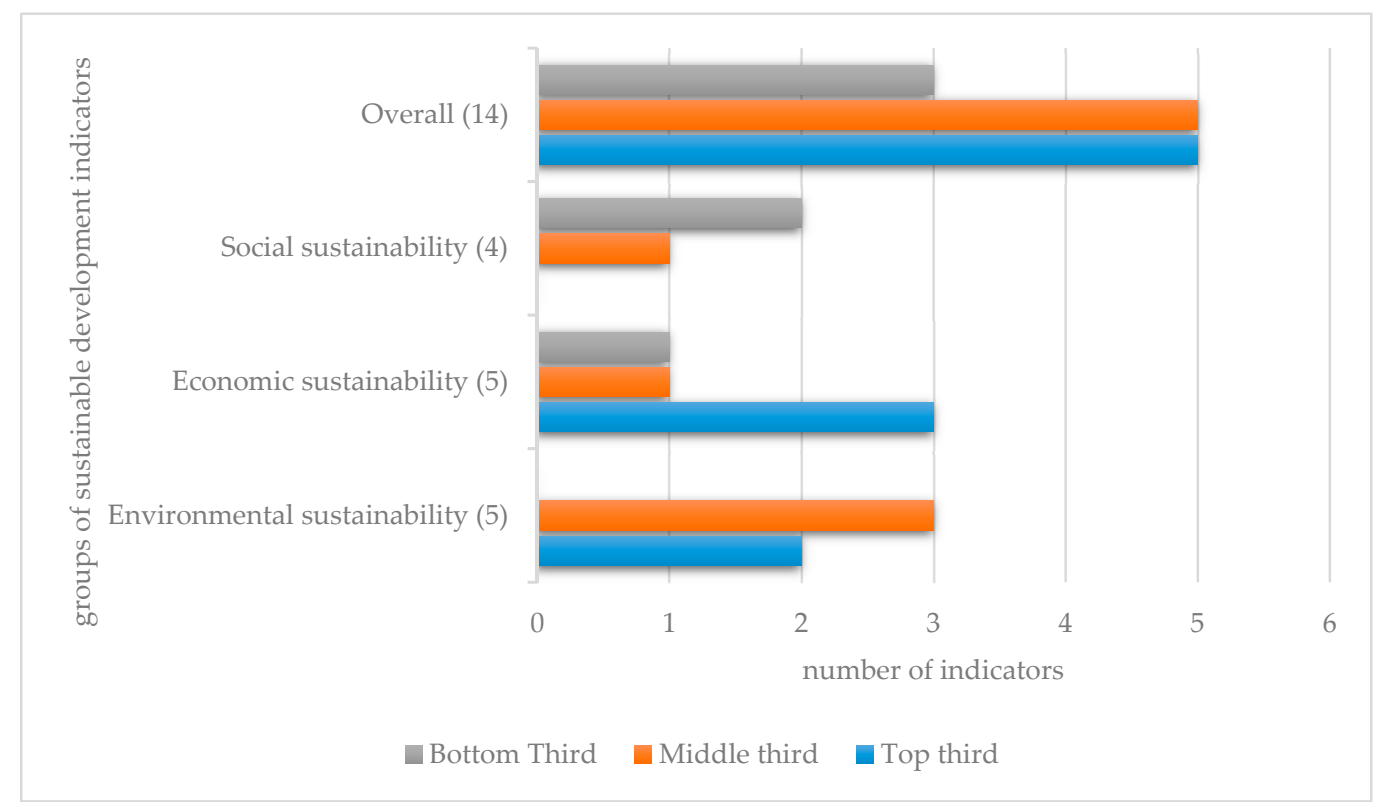

Figure 4. Summary of Romania's performance in the sustainable development dashboard, 2016. Source: [52] (p. 8).

Countries are grouped by each indicator into three groups of approximately equal sizes, thus there is the top third, the middle third and the bottom third. The intention is not to suggest the thresholds or target values for these indicators, but to allow a crude assessment of a country's performance 
relative to others. Figure 4 provides the number of indicators for which Romania performs better than at least two-thirds of countries (it is among the top third of performers), better than at least one-third, but worse than at least one-third (it is among the medium third performers), and worse than at least two-thirds of countries (it is among the bottom third performers). Scores are available for 14 indicators, from which only one is not reported of Romania. The report indicates that Romania performs better in terms of environmental (five indicators) and economic sustainability (five indicators) than in terms of social sustainability (four indicators). The index of social sustainability in the context of corruption shows that social responsibility and social justice, which are also parts of this index, have to be considered when addressing corruption. The risks revolving around corruption are associated with a broad spectrum of negative implications that progressively evolve from the political sphere undermining the rule of law to the economic sphere affecting sustainable development. The ease with which the system alienates state assets comes from the fact that it does not operate with its own money, but with public money. The infiltration of corrupt individuals in the public system, the lack of transparency over the money flow, the lack of private ownership and accountability can lead to disasters and imbalances that are difficult to fix [53].

Corruption can be defined as an abuse of public functions or resources for private benefit [32]. Corruption is described by the following formula proposed by Robert Klitgaard [54]:

$$
\text { Corruption }=\text { monopoly power }+ \text { freedom of decision }- \text { responsibility }
$$

Hence, if in one country the state institutions have monopoly power over resources, freedom of decision and lack of responsibility, all three will lead to a corrupt environment. Considering the internal conditions of each country, societies develop different forms of corruption. In this respect we consider the four types of corruption presented in Table 4.

Table 4. Types of corruption.

\begin{tabular}{|c|c|c|c|c|}
\hline $\begin{array}{c}\text { Types of } \\
\text { Corruption }\end{array}$ & Political Opportunities & Economic Opportunities & $\begin{array}{c}\text { Capacity of State } \\
\text { and Society }\end{array}$ & $\begin{array}{c}\text { Economic } \\
\text { Institutions }\end{array}$ \\
\hline $\begin{array}{l}\text { Influential } \\
\text { markets }\end{array}$ & $\begin{array}{ll} & \\
\text { Mature democracies } \\
- & \text { liberalization } \\
- & \text { competition and } \\
& \text { constant participation }\end{array}$ & $\begin{array}{l}\text { Mature Markets } \\
-\quad \text { liberalized } \\
-\quad \text { open } \\
\text { - } \\
\text { - }\end{array}$ & Strong & High \\
\hline Cartels of elites & 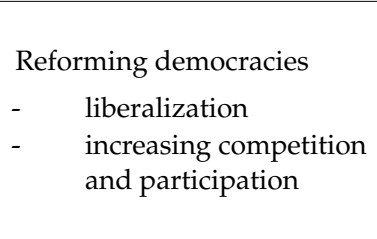 & \begin{tabular}{ll}
\multicolumn{2}{c}{ Reforming Markets } \\
- & high degree of \\
& liberalization \\
& and openness \\
- & increasing competition \\
- & relatively rich
\end{tabular} & Moderate & Medium \\
\hline $\begin{array}{l}\text { Oligarchs and } \\
\text { clans }\end{array}$ & $\begin{array}{l}\text { Transition regimes } \\
-\quad \text { recent liberalization } \\
-\quad \\
\text { significant, but poorly } \\
\text { structured competition }\end{array}$ & $\begin{array}{l}\text { New } \text { Markets } \\
\text { - } \quad \text { major } \\
\text { liberalization lately } \\
\text { - } \quad \begin{array}{l}\text { high degree of inequality } \\
\text { and poverty }\end{array}\end{array}$ & Low & Weak \\
\hline Official moguls & $\begin{array}{l}\text { Undemocratic } \\
-\quad \text { low degree of } \\
\text { liberalization } \\
\text { and openness }\end{array}$ & $\begin{array}{l}\text { New } \text { Markets } \\
\text { - } \quad \text { major } \\
\text { liberalization lately } \\
\text { - } \quad \begin{array}{l}\text { high degree of inequality } \\
\text { and poverty }\end{array}\end{array}$ & Low & Weak \\
\hline
\end{tabular}


It is worth mentioning that there is no country in the world with only one type of manifesting corruption, and the same type of corruption does not look the same in two different countries. Considering the four types of corruption mentioned in Table 4, corruption under the form of influential markets are more common in countries like the USA, while corruption under the form of oligarchs and clans is more common in countries like Romania. According to Johnstone's view, the type of corruption that is also manifesting in Romania shows a low capacity of state and society and weak institutions. Even if Romania has spent almost 30 years out of communism, the economy is structured under the form of new markets with a high degree of inequality and poverty. The political opportunities are still those of transition regimes with significant, albeit poorly-structured competition.

The Corruption Perception Index is no longer considered to be the most accurate index expressing the corruption actual status. This index reveals Romanians' perceptions about certain corrupt behaviors in the public sector such us: bribery, diversion of public funds, use of public office for private gain, nepotism and the civil service and state capture. Transparency International calculates the Corruption Perception Index, which ranks 180 countries by their perceived levels of public sector corruption. The index uses a scale of 0 to 100, where 0 is highly corrupt and 100 is very clean. At the end of 2017 Romania's rank is 59 out of 180 countries. The best performing region is Western Europe with an average score of 66, while Eastern Europe is considered the worst performing region with an average score of 34 [55]. Romania is no longer the most corrupt country in the EU, but its citizens' perception is that they are extremely affected by corruption. This kind of perception is influencing the economic agents' decision to comply or not to paying taxes. For this reason, there is still a large number of economic agents that are deciding not to comply with paying taxes. The phenomenon of corruption is still widespread among European countries. The data showed by the Eurobarometer in October 2017 reveals that $25 \%$ of Europeans think that they are personally affected by corruption in their daily lives. In Romania, over two-thirds (68\%) of respondents say that they are personally affected by corruption. Since 2013, the number of respondents who agree that they are personally affected by corruption slightly dropped in most countries. In Romania there has been a clear increase of $11 \mathrm{pp}$. [50]. The European Research Centre for Anti-Corruption and State-Building in Berlin designed The Index of Public Integrity to give policy makers and civil society actors the evidence to design reform strategies to control corruption. For Romania, the Index of Public Integrity shows a country rank of 30 out of 109 countries at the end of 2017. The index considers: judicial independence, administrative burden, trade openness, budget transparency, e-citizenship, and freedom of the press, as shown in Table 5.

Table 5. Index of Public Integrity.

\begin{tabular}{ccccc}
\hline Components & Component Score & $\begin{array}{c}\text { World Rank } \\
(\mathbf{N}=\mathbf{1 0 9})\end{array}$ & $\begin{array}{c}\text { Regional Rank } \\
\mathbf{( N = 3 0 )}\end{array}$ & $\begin{array}{c}\text { Income Group Rank } \\
\mathbf{( N = \mathbf { 2 8 } )}\end{array}$ \\
\hline Judicial Independence & 5.49 & 52 & 23 & 10 \\
Administrative Burden & 8.96 & 35 & 21 & 5 \\
Trade Openness & 10 & 1 & 1 & 1 \\
Budget Transparency & 8.71 & 20 & 10 & 6 \\
E-Citizenship & 6.05 & 48 & 30 & 10 \\
Freedom of the Press & 6.74 & 40 & 26 & 5 \\
\hline
\end{tabular}

Source: [56].

The Romanian Public Integrity Index reveals that the country is catching up with the EU requirements. The best performance is for trade openness, Romania being on the first place among 109 countries around the world, and also first in the Regional rank. Romania performs worst for the criterion judicial independence (only 5.49 out of 10 points), ranking 52 out of 109 countries. This criterion is most relevant for our study because judicial independence the cornerstone of separation of powers, showing that the judiciary should be independent from the other branches of government. Considering the evolution of Romanian citizens' confidence in state institutions presented 
in Figure 3 and the Index of Public Integrity, we argue that there is a strong need for empowering the relation between state institutions and citizens in order to reduce corruption and increase the level of tax compliance.

The theory supporting this conclusion has its roots in Adam Smith's findings about the fact that a tax rate will diminish the level of the tax base [57]. Entrepreneurs are acting and reacting to the strategies of political decision makers. In terms of marginal tax rates and effective tax rates, the Romanian fiscal system has experienced major difficulties in managing the entrepreneurial environment and in collecting taxes. Both progressive income tax and flat tax were experienced by the Romanian fiscal system in the last decades. However, starting from 1 January 2005 Romania has been under the flat tax regime. In addition to this change, the tax rate was also reduced.

The correlation between the tax rate and the tax base was revised and turned into Arthur Laffer's curve, which brings together the tax rate and the revenue collected by the government.

$$
\downarrow \text { Total revenue }=\uparrow \text { Tax rate } \times \downarrow \text { Tax Base }
$$

The basic theory behind Arthur Laffer's curve shows that changes in tax rates has two effects on the revenues collected. One is the arithmetic effect showing that if the tax rates are lowered, tax revenues will also be lowered by the amount of the decrease in the rate. The second effect is the economic effect revealing that lowering the tax will increase the tax base and also the tax revenue collected [58]. Experience shows it that when the economic and arithmetic effects are combined, the impact of the change in the tax rate over the total tax revenues cannot be anticipated with high accuracy. Using the economic effect of Laffer's curve, the way entrepreneurs behave and how they decide to comply with regard to the tax rate are explained. Based on Laffer's theory, it was demonstrated that beyond a certain tax rate, the amount of revenue collected by the government will decrease even if the tax rate has increased. This theory advocates the argument of the economic effect according to which fewer entrepreneurs comply with paying taxes. Some of them will decide to declare a smaller amount of the profit, while some of them will just quit their business. This will generate negative effects for the economy, because the number of entrepreneurs will decrease and less money will be created in the economy in the future. Therefore, less revenue will be collected by the government, less money will be allocated for health, education, and culture. All these reasons explain the negative correlation between corruption and sustainable development. If entrepreneurs and citizens are not confident in the honesty of the fiscal system, they will try to avoid paying taxes. Such a behavior will create the feeling of making their own justice, or at least of not being cheated. Resources are not allocated in the best possible way and the requirements of the Agenda of Sustainable Development will be increasingly difficult to meet.

Thus, corruption influences the level of sustainable development, by reducing responsibility among entrepreneurs. Therefore, increasing entrepreneurs' responsibility regarding paying taxes as a result of reduced corruption may represent one solution to increase sustainable development. Reduced corruption will generate high levels of responsibility and higher levels of corruption will determine low levels of responsibility. The matter of responsibility is of great importance in the corruption equation, because irresponsibility is both a source and effect of corruption.

\subsection{Hypothesis 4. Digitization Improves Tax Compliance and Reduces Corruption, Both of Which Leading to Increased Sustainable Development in Romania}

The Digital Economy and Society Index (DESI) indicates the progress made by countries in terms of digitization [59]. DESI is structured around five chapters: Connectivity, Human Capital, Use of Internet Services, Integration of Digital Technology, and Digital Public Services. Of particular interest for the purpose of the present paper is the fifth chapter. All reports disclose data pertaining to the previous year. Thus, DESI 2018 refers to the situation of the year 2017. Table 6 presents Romania's performance it terms of Digital Public Services as taken from the reports published in 2014-2018, and the ranking refers to the country's position out of the total 28 Member States of the 
EU. The methodology for DESI 2018 changed. According to the DESI methodology, each new report updates and corrects the previous year's values. This is why the data for DESI 2017 have been updated and expressed according to the new methodology. All the data included in Table 6 are compiled from all reports, 2014-2018, using the final, corrected and most recent values.

Table 6. Digital Public Services—Romania vs. EU, 2017-2018.

\begin{tabular}{cccc}
\hline \multirow{2}{*}{ Digital Public Services } & \multicolumn{2}{c}{ Romania } & \multirow{2}{*}{ EU Score } \\
\cline { 2 - 3 } & Rank & Score & \\
\hline DESI 2018 & 26 & 41.4 & 57.5 \\
DESI 2017 & 26 & 37.1 & 53.7 \\
DESI 2016 & 28 & 0.21 & 0.51 \\
DESI 2015 & 28 & 0.27 & 0.54 \\
DESI 2014 & 25 & 0.27 & 0.45 \\
\hline
\end{tabular}

Source: [60].

Romania's ranking indicates a very poor performance in this respect, despite the obvious progress made during the last two years. The indicator composition is described in Table 7 below, whose purpose is to highlight where the main progress has been recorded. Because of changes in methodology for DESI 2018, as well in the composition of the Digital Public Services index over years, data is comparable only for the last two years.

Table 7. Digital Public Services—evolution by components, Romania vs. EU, 2017-2018.

\begin{tabular}{|c|c|c|c|c|c|}
\hline \multirow{3}{*}{ Component } & \multicolumn{4}{|c|}{ Romania } & \multirow{3}{*}{ EU DESI 2018} \\
\hline & \multicolumn{2}{|c|}{ DESI 2018} & \multicolumn{2}{|c|}{ DESI 2017} & \\
\hline & Value & Rank & Value & Rank & \\
\hline $\begin{array}{l}\text { 5a1 eGovernment Users } \\
\text { (\%internet users needing to submit forms) }\end{array}$ & $80 \%$ & 7 & $84 \%$ & 4 & $58 \%$ \\
\hline $\begin{array}{l}\text { 5a2 Pre-filled Forms } \\
\text { (Score: } 0 \text { to } 100 \text { ) }\end{array}$ & 12 & 28 & 12 & 27 & 53 \\
\hline $\begin{array}{l}\text { 5a3 Online Service Completion } \\
\text { (Score: } 0 \text { to 100) }\end{array}$ & 61 & 28 & 55 & 28 & 84 \\
\hline $\begin{array}{l}\text { 5a4 Digital Public Services for Businesses } \\
\text { (Score: } 0 \text { to } 100 \text {, including domestic and cross-border) }\end{array}$ & 51 & 28 & 48 & 28 & 83 \\
\hline $\begin{array}{l}5 \mathrm{a} 5 \text { Open Data } \\
\text { (\% of maximum score) }\end{array}$ & $79 \%$ & 10 & $63 \%$ & 11 & $73 \%$ \\
\hline $\begin{array}{l}5 \mathrm{a} 6 \text { eHealth Services } \\
\text { (\% individuals })\end{array}$ & $11 \%$ & 21 & $\mathrm{~N} / \mathrm{A}$ & - & $18 \%$ \\
\hline
\end{tabular}

Source: [59].

The fields in which Romania performs above the EU average are eGovernment Users and Open Data. The country report reveals that $80 \%$ of the internet users who needed to submit forms to the public administration chose governmental portals in the year 2017, which indicates a slight decrease compared to the previous year 2016, when $84 \%$ of the users used governmental portals. Such a decrease worsened Romania's ranking, falling from the fourth position to the seventh position. In terms of Open Data, Romania's score is 79\% in 2017, compared to 63\% in 2016; the EU average for 2017 is 73\%. In this respect, Romania improved its position, its ranking going down from 11th to 10th.

Despite these two improvements and above-average satisfactory rankings, Romania ranks 28th in 28 countries in terms of: Pre-filled Forms, Online Service Completion, and Digital Public Services for Businesses. Although the score for the last two components improved from 2016 to 2017, the ranking did not change. The score for Pre-Filled Score remained the same, which relegated Romania from the 
27th to the very last position among the EU Member States. The overall poor performance of Romania places the country on the 26th position among the 28 EU Member States in terms of Digital Public Services and on the 28th position for DESI.

Other European statistics regarding Romanian eGovernment are discontinuous and obsolete. The same holds true for statistics collected domestically. Thus, the eGovernment online availability is reported only for the period 2007-2009 to be 37.5, 47.5, and 60\% respectively. Updated information is unavailable [61]. The degree to which the population aged 16-74 used the internet in the last 3 months to access public authorities' websites is measured for the period 2007-2010, the weights being: 5.3, 9.4, 6.3 , and $6.9 \%$ respectively [62].

Important progress was made by Romania in terms of eGovernment when it introduced mandatory e-filing of certain tax statements [63]. Thus, according to the Order of the President of the National Agency for Fiscal Administration (NAFA) no. 2326/2 August 2017 regarding certain tax statements that should be submitted by electronic means or by long distance systems, published in the Official Gazette no. 649/8 August 2017, a number of 13 tax forms can only be submitted electronically, via internet, on the NAFA website. Table 8 below presents the respective tax statements.

Table 8. Tax statements that are to be submitted electronically, via internet on the NAFA website.

\begin{tabular}{|c|c|}
\hline Tax Statement Code & Tax Statement Denomination \\
\hline Form 100 & Statement regarding the liabilities due to the State Budget \\
\hline Form 101 & Statement regarding corporate income tax \\
\hline Form 120 & Excise duties return \\
\hline Form 205 & $\begin{array}{l}\text { Informative statement regarding the withheld tax, income derived from gambling and } \\
\text { gains/losses derived from investments for income beneficiaries }\end{array}$ \\
\hline Form 207 & $\begin{array}{l}\text { Informative statement regarding the withheld tax/exempt incomes for non-resident income } \\
\text { beneficiaries }\end{array}$ \\
\hline Form 208 & $\begin{array}{l}\text { Informative statement regarding the tax on the income derived from the transfer of the real } \\
\text { estate property from the personal property }\end{array}$ \\
\hline Form 300 & Value added tax return \\
\hline Form 301 & Special value added tax return \\
\hline Form 307 & $\begin{array}{l}\text { Statement regarding the amounts resulting from the adjustment/correction of the } \\
\text { adjustment/VAT regularization }\end{array}$ \\
\hline Form 311 & $\begin{array}{l}\text { Statement regarding output VAT due by taxable persons whose VAT registration number has } \\
\text { been cancelled as per art. } 316 \text { para. (11) letters (a)-(e), letter (g) or letter (h) of Law no. 227/2015 } \\
\text { regarding the Tax Code }\end{array}$ \\
\hline Form 390 & $\begin{array}{l}\text { Recapitulative statement regarding the intra-Community supplies/acquisitions of } \\
\text { goods/services }\end{array}$ \\
\hline Form 394 & $\begin{array}{l}\text { Informative statement for local supplies of goods/services and acquisitions performed within } \\
\text { the national territory by taxable persons registered for VAT purposes }\end{array}$ \\
\hline Form 710 & Rectifying statement \\
\hline
\end{tabular}

In addition, Ernst \& Young also notes that several European countries, Romania included, have been considering the adoption of Standard Audit File for Tax (SAF-T) requirements. SAF-T is an electronic format for efficient transfer of accounting data from companies to tax authorities or external auditors [64].

The eGovernment report for Romania published in 2016 reveals other legislative actions, which include Government Ordinance no. 24/2002 on the collection of local taxes by electronic means. According to this ordinance, municipalities and cities in Romania have the obligation to develop electronic systems for local tax collection that provide citizens with access to the relevant information on local taxes and solutions to pay such taxes. This ordinance is supplemented by Law no. 291/2002 on the electronic payment of local taxes, according to which local public administration authorities have to take all necessary measures to inform citizens about electronic payment of 
local taxes. The existing infrastructure to pay taxes online is provided by the 'Virtual Payment Office' (in Romanian, 'Ghiseul Virtual de Plati'), which facilitates taxpayers' interaction with the public administration by providing electronic payment solutions via bank cards of fines, taxes, fees and other tax obligations related to salary income and incomes from: commercial activities, liberal professions, intellectual property rights, transfer of use of goods, transfer of securities, contractual term buying/selling operations of currency, agricultural activities, real estate property transfer, income taxes, unemployment, and benefits. Assessment and notification of income taxes, unemployment benefits and health contributions, as well as corporate tax declaration and notification have been recently implemented on e-guvernare.ro and on the website of the National Agency for Fiscal Administration [65].

Doing Business 2019 Report for Romania reveals the following achievements in terms of digitization [66]:

- the year 2012 is the starting point when Romania made paying taxes easier for companies by introducing an electronic payment system and a unified return for social security contributions, while abolishing the annual minimum tax; in 2015, the process of simplifying paying taxes continued, with the majority using the electronic system for filing and paying taxes

- the trade register office electronically obtains the fiscal record certificates

- employers are to have an internal general register record of all their employees in electronic format, which is then transmitted to the Territorial Labor Inspectorate

- there is a collateral registry in operation for both incorporated and non-incorporated entities, which is unified geographically and by asset type with an electronic database indexed in the debtor's name

- a score of 2 out of 8 regarding the format in which the majority of title or deed records are kept in the largest business city

- a score of 1 out of 4 for paying court fees electronically within the competent court

- a score of 1 out of 8 for the electronic database for recording boundaries, checking plans, and providing cadastral information (geographic information system)

- a score of 0 out of 8 regarding the format in which the majority of maps of land plots are kept in the largest business city - this means they are entirely kept on paper

- there is no electronic database for checking encumbrances (liens, mortgages, restrictions)

The data above clearly indicate the progress made by Romania since the year 2012 in terms of eGovernment and digital public services. However, progress is slow and discontinuous, and the existing comparable data about this process-i.e., two years-cannot allow for a quantitative analysis of variables. However, as already stated in Section 3.1, the introduction for the first time of an electronic tax payment system in Romania led to a substantial decrease in the time spent to achieve tax compliance. A decrease in the time spent increases the level of tax compliance; tax compliance being one way of decreasing corruption, it is legitimate to argue that the digitization of public services, through eGovernment, could lead to a lower level of corruption and increased sustainable development.

\section{Discussion}

The research conducted clearly indicates that the influence of entrepreneurial efforts made towards tax compliance is higher than the burden of the tax itself. In other words, the time and financial resources spent to compile and prepare tax documents are a major determinant of entrepreneurs' decision to pay taxes or not. Although the amount of taxes may unfairly be invoked as the primary source of tax non-compliance, Hypothesis 1 casts light on this matter. Insofar as the time spent for tax compliance is concerned, it has been found that there is a positive correlation between the number of existing taxes and the time spent for tax compliance. Cumbrous bureaucracy and administrative procedures keep the time spent for tax compliance at high levels even when the number of taxes 
remains constant. Indeed, the time spent for tax compliance decreased only when the administrative procedures and tax regulations were simplified and when the electronic tax payment system became effective. Moreover, the administrative tax burden reflected by the number of taxes influences the number of hours spent for tax compliance and the decrease in the number of taxes diminishes the time spent for tax compliance. Although the amount of taxes due by companies also determines the level of compliance, the influence of this factor is weaker than the above-mentioned factors.

The analysis has also unveiled that burdensome tax regulations are a determinant of corruption occurrence or spread in Romania. To this purpose, the analysis of Hypothesis 2 uncovers that the phenomenon of corruption, the effects of which can be both evasive and destructive to entrepreneurship, cannot be merely explained by tax regulations and tax burden. Corruption in its most severe forms covers irregular payments and bribes, favoritism in decisions of government officials, as well as diversion of public funds. Such phenomena are associated with rent-seeking behaviors and state capture. Favoritism in decisions and discretionary power in allocating public funds signal the need to resort to corrupt behaviors such as irregular payments and bribes. Such behaviors are meant only partly to decrease costs of compliance, i.e., evasive entrepreneurship. However, the spread of the governmental agency interventionism sheds light on how extra-market benefits are obtained by corrupt entrepreneurs to the detriment of competitors and taxpayers, i.e., destructive entrepreneurship.

Accession to the EU brought about higher citizens' confidence after a period of declining levels. The Romanians' confidence in state institutions is weaker than that of their European counterparts. In addition, Romania performs better in terms of environmental and economic sustainability and worse in terms of social sustainability. This finding helps to check Hypothesis 3, which states that the spread of corruption endangers the process of sustainable development. Indeed, the social sustainability component of the Human Development Report comprises social responsibility and social justice. Low scores for such indicators are factors explaining high levels of corruption. In this context, corruption stems from a mixture of monopoly power over resources, freedom of decision, and lack of responsibility on behalf of the state institutions. The data presented indicate that Romania has a low score for judicial independence, which is relevant for checking the present hypothesis-an independent justice is a prerequisite of corrupt-free business environment in particular and society in general. Overall, lower levels of corruption generate higher levels of responsibility, which in turn is positively correlated with sustainable development.

Last but not least, Hypothesis 4 states that digitization can improve tax compliance and reduce corruption, thus increasing the level of sustainable development in Romania. Unfortunately, the digital society and economy of Romania is among the least developed from Europe. Romania has occupied one of last positions in the DESI ranking over the years. As far as tax compliance is concerned, it can be positively influenced by better digital public services for business and eGovernment. However, despite an above-the-EU-average performance in terms of the latter, Romania is the last in the EU in the following matters: pre-filled forms, online service completion and digital public services. In addition to a poor development of the supply-side of such services, Romania has a low rate of Internet use as compared to the other EU countries. The lack of interest and poor performance in digitization is also reflected by inexistent or discontinuous and obsolete data on digitization. However, progress has been made in terms of submitting tax forms, a certain number of such forms being submitted only electronically. The year 2012 represents the very birth of the electronic tax payment system, and Romania is still far from managing to include all administrative procedures related to tax compliance in the online environment. However, the implementation of the system led to a substantial decrease in the time spent to achieve tax compliance, as was previously shown when checking Hypothesis 1.

Digital pubic services may increase tax compliance and reduce corruption, in an attempt to achieve higher levels of sustainable development in Romania. The use of digital public services reduces costs for entrepreneurs and increases their confidence in state institutions due to higher levels of transparency. This creates prerequisites for higher revenues to the budget and for a better use 
of present and future resources. All arguments mentioned above are premises for a higher level of sustainable development in Romania.

\section{Conclusions}

Hence, a balanced conclusion of all considerations mentioned above is that sustainable development in Romania can be improved through digitization by increasing tax compliance and reducing corruption. The costs generated by compliant behavior influence the entrepreneurs' decision in the fiscal environment. It is worth highlighting that the influence of entrepreneurial efforts made towards tax compliance is higher than the burden of the tax itself and that demanding regulations could represent a source of corruption. However, corruption cannot be solely explained through the lens of tax regulations. We argue that one way to diminish the entrepreneurs' efforts to comply with tax regulations is the digitization of the tax declaration and payment system.

The present research can provide useful and valuable insights for decision makers in the process of fighting the corruption arising from entrepreneurs' behaviors and of achieving sustainable development. The macroeconomic analysis proposed herein is original in that, to the best of the authors' knowledge, no similar study has been done before. In addition, the topic itself is novel as digitization and eGovernment matters have only recently penetrated academic debate.

The main limitation of the present study is the lack of consistent and continuous data regarding digitization in Romania. However, meaningful results have been obtained using the extant data. Future research is necessary to investigate the role of digitization in the process of achieving higher levels of sustainable development, and such an undertaking will be possible provided that more data is available. The present research, which discusses the existing correlations between the investigated variables, can be extended to include a causality analysis aimed at mitigating the endogeneity problem. To this purpose, the approach could consist in lagging the independent variables-e.g., the cost of tax compliance, which is correlated with extra payments/bribes/favoritism as dependent variable-using a mediating variable or adding time-variant control variables to the analysis.

Author Contributions: All the authors have contributed to the whole development of the manuscript: designing the research, performing the calculations, writing the text, discussing the results, and obtaining the conclusions.

Funding: The research published in this article has been supported by the Romanian government through CERTRAN project-The Upgrade of the Research Capacity in Economics through Development of a Transdisciplinary Research Infrastructure.

Conflicts of Interest: The authors declare no conflict of interest.

\section{References}

1. Popescu, G.H.; Davidescu, A.A.M.; Huidumac, C. Researching the Main Causes of the Romanian Shadow Economy at the Micro and Macro Levels: Implications for Sustainable Development. Sustainability 2018, 10, 3518. [CrossRef]

2. Li, Z.F. Endogeneity in CEO Power: A Survey and Experiment. Invest. Anal. J. 2016, 45, 149-162. [CrossRef]

3. Kim, E.; Ha, Y.; Kim, S. Public Debt, Corruption and Sustainable Economic Growth. Sustainability 2017, 9, 433. [CrossRef]

4. Buchanan, J.M.; Gordon, T. The Collected Works of James M. Buchanan, Volume 3, The Calculus of Consent. Logical Foundations of Constitutional Democracy; Liberty Fund: Indianapolis, IN, USA, 1999.

5. North, D.C. Institutions. J. Econ. Perspect. 1991, 5, 97-112. [CrossRef]

6. North, D.C. Understanding the Process of Economic Change; Princeton University Press: Princeton, NJ, USA, 2005; pp. 103-115. ISBN 0-691-11805-1.

7. North, D.C. Instituţii, Schimbare Instituţională şi Performanţă Economică ; Î.E.P. Ştiinţa: Chişinău, Moldova, 2003; pp. 11-12. ISBN 9975-67-370-8. (In Romanian)

8. Williamson, O.E. The New Institutional Economics: Taking Stock, Looking Ahead. J. Econ. Lit. 2000, 38, 595-613. [CrossRef] 
9. Fudulu, P. Teoria Culturilor şi Instituţiilor: Determinarea Culturală a Performanţelor Economice; Editura Universitară: București, Romania, 2007; pp. 139-142. ISBN 978-973-749-132-9. (In Romanian)

10. Pană, C.M. Economia Instituțională a Mediului Educațional și Antreprenorial din România; Editura ASE: București, Romania, 2018; pp. 53-54. ISBN 978-606-34-0247-0. (In Romanian)

11. Boettke, P.J.; Coyne, C.J. Entrepreneurship and development: Cause or consequence? In Advances in Austrian Economics; Koppl, R., Birner, J., Kurrild-Klitgaard, P., Eds.; Emerald Group Publishing Limited: Bingley, UK, 2003; Volume 6, pp. 67-87. ISBN 978-0-76231-041-8.

12. Boettke, P.J.; Coyne, C.J.; Leeson, P.T. Institutional Stickiness and the New Development Economics. Am. J. Econ. Sociol. 2008, 67, 331-358. [CrossRef]

13. Baumol, W.J. Entrepreneurship: Productive, Unproductive, and Distructive. J. Polit. Econ. 1990, 98, 893-921. [CrossRef]

14. Sautet, F.E. The Role of Institutions in Entrepreneurship: Implications for Development Policy. In Mercatus Policy Series; Policy Primer no. 1; Mercatus Center: Arlington, VA, USA, 2005; pp. 1-18.

15. Sobel, R.S. Testing Baumol: Institutional quality and the productivity of entrepreneurship. J. Bus. Ventur. 2008, 23, 641-655. [CrossRef]

16. Boettke, P.J.; Fink, A. Institutions first. J. Econ. 2011, 7, 499-504. [CrossRef]

17. Acemoglu, D.; Johnson, S.; Robinson, J. Institutions as a fundamental cause of long-run growth. In Handbook of Economic Growth; Aghion, P., Durlauf, S.N., Eds.; North Holland Publishing Co.: Amsterdam, The Netherlands, 2005; Volume 1A, pp. 386-464. ISBN 9780444520418.

18. Acemoglu, D. Institutions, Factor Prices, and Taxation: Virtues of Strong States? Am. Econ. Rev. 2010, 100, 115-119. [CrossRef]

19. Acemoglu, D.; Robinson, J.A. De ce Eșuează Națiunile; Litera: Bucuresti, Romania, 2012; pp. $409-447$. ISBN 978-606-33-0025-07. (In Romanian)

20. Baumol, W.J.; Litan, R.E.; Schramm, C.J. Capitalismul Bun, Capitalismul Rău şi Economia Dezvoltării şi a Prosperităţii; Polirom: Iaşi, Romania, 2009; p. 12. ISBN 978-973-46-1104-1. (In Romanian)

21. Hébert, R.F.; Link, A.N. In Search of the Meaning of Entrepreneurship. Small Bus. Econ. 1989, 39-49. [CrossRef]

22. Henrekson, M.; Sanandaji, T. The interaction of entrepreneurship and institutions. J. Econ. 2011, 7, 47-75. [CrossRef]

23. Garud, R.; Hardy, C.; Maguire, S. Institutional Entrepreneurship as Embedded Agency: An Introduction to the Special Issue. Organ. Stud. 2007, 28, 957-969. [CrossRef]

24. Leeson, P.T.; Boettke, P.J. Two-Tiered Entrepreneurship and Economic Development. Int. Rev. Law Econ. 2009, 29, 252-259. [CrossRef]

25. Holcombe, R.G. Political Entrepreneurship and the Democratic Allocation of Economic Resources. Rev. Austrian Econ. 2002, 15, 143-159. [CrossRef]

26. Buchanan, J.M.; Tullock, G. Calculul Consimțământului: Fundamentele Logice ale Democrației Constiuționale; Publica: București, Romania, 2010; pp. 356-372. ISBN 978-973-1931-27-2. (In Romanian)

27. Buchanan, J.M. Limitele Libertăţii: Intre Anarhie şi Leviathan; Institutul European: Iași, Romania, 1997; pp. 219-226. ISBN 973-586-038-4. (In Romanian)

28. Selke, S.; Mallick, B.; Holzbach, A. e-Honesty: Technical Potentials and Social Risks of Local e-Government Strategies in Bangladesh for Supporting the Fight against Corruption. In Proceedings of the 8th European Conference on eGovernment, Lausanne, Switzerland, 10-11 July 2008; Remenyi, D., Ed.; Acad. Conferences Ltd.: Reading, UK, 2008; pp. 475-482.

29. Foley, J.; Galllery, K. An Investigative Study of Promoting Awareness and Increasing Registration of PAYE Anytime in the Border Midlands West Region. In Proceedings of the 12th European Conference on eGovernment, Barcelona, Spain, 14-15 June 2012; Gasco, M., Ed.; Acad. Conferences Ltd.: Reading, UK, 2012; pp. 227-233.

30. Klun, M. Does eTaxation Reduce Taxation Compliance Costs. In Proceedings of the 11th European Conference on eGovernment, Ljubljana, Slovenia, 16-17 June 2011; Klun, M., Decman, M., Jukic, T., Eds.; Acad. Conferences Ltd.: Reading, UK, 2011; pp. 335-338.

31. Leake, S. Risk Analysis, or How to Avoid Contact with Most of Your Customers. In Proceedings of the 8th European Conference on eGovernment, Lausanne, Switzerland, 10-11 July 2008; Remenyi, D., Ed.; Acad. Conferences Ltd.: Reading, UK, 2008; pp. 347-352. 
32. Xia, H.; Tan, Q.; Bai, J. Corruption and Technological Innovation in Private Small-Medium Scale Companies: Does Female Top Management Play a Role? Sustainability 2018, 10, 2252. [CrossRef]

33. Johnstone, M. Corupţia şi Formele Sale. Bogăţie, Putere şi Democraţie; Editura Polirom: Bucharest, Romania, 2007; p. 31. ISBN 978-973-46-0446-3. (In Romanian)

34. World Bank. Data Bank. Data Catalog, doing Business. Available online: http://databank.worldbank.org/ data / reports.aspx?source=doing-business (accessed on 27 November 2018).

35. World Bank, Doing Business. Measuring Business Regulations. Methodology. Available online: http: / / www.doingbusiness.org/en/methodology/paying-taxes (accessed on 27 November 2018).

36. World Economic Forum. The Global Competitiveness Report 2018. Downloads. Data Set. Available online: http:/ /reports.weforum.org/global-competitiveness-report-2018/downloads/ (accessed on 3 December 2018).

37. World Bank, Doing Business 2012. Economy Profile: Romania. Available online: https:/ /openknowledge. worldbank.org/bitstream/handle/10986/26999/654500Romania00BOX0365768B00PUBLIC0.pdf? sequence $=1 \&$ isAllowed $=y$ (accessed on 3 December 2018).

38. Pană, M.C.; Staicu, G.S. Institutional Framework, Transaction Costs and Entrepreneurship. An Analysis of the Romanian Business Environment. In The International Conference in Economics and Administration, Proceedings of the International Conference in Economics and Administration, Bucharest, Romania, 5-6 June 2015; Druică, E., Ed.; Editura Universității din București: București, Romania, 2015; pp. 299-309.

39. Coase, R.H. The Nature of the Firm. Econ.-New Ser. 1937, 4, 386-405. [CrossRef]

40. Allen, D.W. Transaction Costs. In Encyclopedia of Law and Economics; Bouckaert, B., De Geest, G., Eds.; Edward Elgar: Cheltenham, UK, 2000; Volume 1, pp. 893-926. ISBN 1-85898-984-1.

41. Alchian, A.A. Some Implications of Recognition of Property Right Transaction Costs. In Economics and Social Institutions; Brunner, K., Ed.; Springer: Dordrecht, The Netherlands, 1979; Volume 1, pp. 233-254. ISBN 978-94-009-9259-7.

42. Dang, C.; Li, Z.F.; Yang, C. Measuring firm size in empirical corporate finance. J. Bank. Financ. 2018, 86, 159-176. [CrossRef]

43. Fraser Institute. Economic Freedom of the World: 2018 Annual Report. View the Data Set-Data for Researchers. Available online: https: / / www.fraserinstitute.org/resource-file?nid=12378\&fid=10644 (accessed on 11 December 2018).

44. Gwartney, J.; Lawson, R.; Hall, J.; Murphy, R. Economic Freedom of the World: 2018 Annual Report, 2018 ed.; Fraser Institute: Vancouver, BC, Canada, 2018; pp. 224-225. ISBN 978-0-88975-505-5.

45. World Economic Forum. Global Competitiveness Index 2017-2018. Appendix A: Methodology and Computation of the GCI 2017-2018. Available online: http:/ / reports.weforum.org/global-competitivenessindex-2017-2018/appendix-a-methodology-and-computation-of-the-global-competitiveness-index-20172018/ (accessed on 11 December 2018).

46. World Economic Forum. Global Competitiveness Index 2017-2018. Appendix D: Technical Notes and Sources. Available online: http:/ / reports.weforum.org/global-competitiveness-index-2017-2018/appendixd-technical-notes-and-sources / (accessed on 11 December 2018).

47. Sustainable Development Goals. 17 Goals to Transform Our World. Available online: https://www.un.org/ sustainabledevelopment/sustainable-development-goals/ (accessed on 18 December 2018).

48. Sustainable Development Goals. Knowledge Platform: Progress of Goal 16 in 2018. Available online: https:/ / sustainabledevelopment.un.org/sdg16 (accessed on 18 December 2018).

49. European Commission. Public Opinion in the European Union. Standard Eurobarometer 90. November 2018. Available online: http:/ / ec.europa.eu/commfrontoffice/publicopinion/index.cfm/Survey/index\#p=1\& instruments=STANDARD (accessed on 22 January 2019).

50. European Commission. Public Opinion in the European Union. Eurobarometer A-Z. Special Eurobarometer 470. Corruption. Summary. October 2017. Available online: http://ec.europa.eu/commfrontoffice/ publicopinion/index.cfm/Survey/getSurveyDetail/instruments/SPECIAL/surveyKy/2176 (accessed on 23 January 2019).

51. Sustainable Development Goals. Knowledge Platform: Progress of Goal 17 in 2018. Available online: https:/ / sustainabledevelopment.un.org/sdg17 (accessed on 18 December 2018). 
52. United Nations Development Programme. Human Development Reports. Human Development Indicators. Human Development for Everyone. Briefing Note for Countries on the 2016 Human Development Report: Romania. Available online: http://hdr.undp.org/en/countries/profiles/ROU. (accessed on 4 January 2019).

53. Voicu, C. Indreptar de Economie Subterană. Abordare Multidimensională a Eşecului Raţionalităţii Economice; Editura ASE: Bucharest, Romania, 2015; p. 112. ISBN 978-606-505-882-8. (In Romanian)

54. Klitgaard, R. International Cooperation against Corruption. Financ. Dev. 1998, 1998, 3-6.

55. Transparency International. Surveys, Corruption Perceptions Index 2017, 21 February 2018. Available online: https:/ / www.transparency.org/news/feature/corruption_perceptions_index_2017 (accessed on 4 January 2019).

56. Mungiu-Pippidi, A.; Dadasov, R.; Kukutschka, R.M.B.; Alvarado, N.; Dykes, V.; Kossow, N.; Khaghaghordyan, K.; Index of Public Integrity. European Research Centre for Anti-Corruption and State-Building (ERCAS). 2017. Available online: https:/ integrity-index.org/country-profile/?id=ROM\& yr=2017 (accessed on 19 November 2018).

57. Smith, A. An Inquiry into the Nature and Causes of the Wealth of Nations; Edwin Cannan: London, UK, 1776; ISBN 0865970068.

58. Laffer, A.B. The Laffer Curve: Past, Present, and Future, The Heritage Foundation. Available online: https:/ / www.heritage.org/research/taxes/bg1765.cfm (accessed on 18 February 2019).

59. European Commission. Digital Economy and Society Index (DESI) 2018. Country Report Romania. 2018. Available online: http:/ / ec.europa.eu/information_society/newsroom/image/document/2018-20/ ro-desi_2018-country-profile_eng_199394CB-B93B-4B85-C789C5D6A54B83FC_52230.pdf (accessed on 17 November 2018).

60. European Commission. Digital Economy and Society Index (DESI). Romania. Available online: https: / / ec.europa.eu/digital-single-market/en/scoreboard/romania (accessed on 8 December 2018).

61. INSSE. eGovernment Online Availability. Available online: http://www.insse.ro/cms/files/Web_IDD_BD_ ro/O13/O13_4-Disponibilitatea\%20guvernarii.xls (accessed on 17 November 2018).

62. INSSE. Share of Individuals Aged 16 to 74 in the Last Three Months for Interaction with Public Authorities in the Total Individuals Aged 16-74. Available online: http:/ / www.insse.ro/cms/files/Web_IDD_BD_ro/ O13/O13_5-Utilizarea\%20guvernarii\%20electronice.xls (accessed on 17 November 2018).

63. Ernst \& Young. Global Tax Alert. Romania Introduces Mandatory E-Filing of Certain Tax Statements. 2017. Available online: https://www.google.ro/search?q=romania+tax+filing+ey\&spell= $1 \&$ sa=X\&ved=0ahUKEwis6IjttNveAhVMkSwKHZouDZoQBQgoKAA\&biw=1242\&bih=597 (accessed on 17 November 2018).

64. Ernst \& Young. Digital Tax Administration Trends-Timeline. Available online: http://cdn.instantmagazine. com/upload/6014/ey-000053126_indirect_tax_thought_leadership_1.ac4869b7e5a8.pdf (accessed on 17 November 2018).

65. European Commission. eGovernment in Romania. 2015. Available online: https://joinup.ec.europa.eu/ sites / default/files /inline-files/eGovernment\%20in\%20Romania\%20-\%20February\%202016\%20-\%20v1_ 00.pdf (accessed on 17 November 2018).

66. World Bank, Doing Business 2019. Romania. 16th Edition. 2018. Available online: http:/ /www.doingbusiness. org/content/dam/doingBusiness/country/r/romania/ROM.pdf (accessed on 17 November 2018).

(C) 2019 by the authors. Licensee MDPI, Basel, Switzerland. This article is an open access article distributed under the terms and conditions of the Creative Commons Attribution (CC BY) license (http://creativecommons.org/licenses/by/4.0/). 